\title{
TICHÁ OSLAVA ODLIŠNOSTI. EMPATICKÁ POEZIE OSTAPA SLYVYNSKÉHO
}

\section{HELENA PAZDIOROVÁ}

\section{A SILENT CELEBRATION OF DISSIMILARITY. EMPATHETIC POETRY OF OSTAP SLYVYNSKY}

ABSTRACT This paper is focused on poetry of Ukrainian poet Ostap Slyvynskyy. It analyses all his poetry output so far (1998-2018) with emphasis on his later poetry collections. It takes a look into his characteristic themes: universal human stories, fragile interpersonal relationships, forming of identity, an experience of being rejected etc., and their connection to biblical and mythological motifs which are frequently used in Slyvynsky's poems.

KEY WORDS Ukrainian literature, contemporary Ukrainian poetry, Ostap Slyvynsky, spiritual poetry

CONTACT Department of Slavonic Studies, Faculty of Arts, Palacký University Olomouc, helena.pazdiorovao1@upol.cz 
Spirituálně a meditativně laděná poezie má na Ukrajině dlouhou tradici, která se jako červená nit táhne celou historií tamní literatury. Ukrajina jakožto země, kde víra zaujímá v životě lidí důležité místo, je logicky pro tento směr dobrou živnou pưdou. Nabízí se srovnání se situací $\mathrm{v}$ české literatuře - u nás se s poezií podobného směřování nesetkáváme tak často, navíc má menší roli i dosah. Není to jen současný stav, jde o dlouhodobější vývoj. Podíváme-li se třeba na neoficiální básnickou tvorbu v 60. či 70. letech minulého století, česká poezie nabízí tř̌eba i texty ironické a experimentální (viz např. poezie Václava Havla), kdežto ukrajinští spisovatelé se noří výhradně do tematizace víry, morálky, dějinných paralel a zahloubávají se do lidského nitra. Obecně se dá říct, že zatímco české literatuře je mnohem více vlastní určité odlehčení a civilnost projevu, v té ukrajinské je naopak základním naladěním jistá tíha - vážnost, dramatičnost a patos.

Jedním z autorů, které na Ukrajině lze přiřadit ke spirituální a meditativní linii, je básník Ostap Slyvynskyj (1978). Ten se naopak snaží patosu vyvarovat. Následující text se pokusí analyzovat některé osobité roviny autorovy tvorby, díky nimž si jeho poezie na poli ukrajinské literatury již vydobyla nenahraditelnou pozici.

\section{1 / NAHLÉDNUTÍ ZA OPONU}

Ostap Slyvynskyj vydal dosud pět básnických sbírek. Už v debutovém Жертвоприношення великої puби (Obětování velké ryby, 1998) se ustanovuje jeho typické emoční naladění založené na intimitě, klidu a rozvážnosti. Básník šetří slovy a velkými metaforami, snaží se o stručná vyjádření. Básně jsou často zasazeny do přírodních kulis, hledání krásy a harmonie v př́rodě patří $\mathrm{k}$ základním kamenům sbírky. Pozdější texty se přesouvají více $\mathrm{k}$ lidským příběhům. S každou další vydanou knihou Slyvynskyj postupně svou poetiku zdokonaluje a hledá ideální formu vyjádření, avšak hlavní témata zůstávají podobná.

Básník rád pracuje s všeobecně známými postavami z biblických a mytických příběhů. Před využitím v básni je však zbaví všech historických a kulturních vrstev a nánosů a ponechá jen jejich základní, archetypální kostru. Mnohem víc než na křestanském (a jiném) kontextu mu totiž záleží na hledání, vnímání, chápání a prozkoumávání něčeho obecně lidského, po generace neměnného.

Slyvynskyj k těmto univerzálním lidským příběhưm přistupuje s opatrností a s velkou mírou empatie. Ve svých básních, velmi často narativních, zkoumá podněty a pohnutky postav, odkrývá jejich nejniternější pocity. Zdůrazňuje všednost a všeobecnost těchto příběhů, snaží se dobrat $\mathrm{k}$ jejich samotné podstatě. A vydává se ještě dál: pátrá po tom, co jim předcházelo. Hledá odpovědi na široké otázky, co formuje člověka, jeho identitu a jeho charakter. Načrtává drobné epizody lidského života a ukazuje, že právě ony mohou být rozhodující pro jeho další směřování.

Dobře to ilustruje úvodní báseň zatím poslední Slyvynského sbírky Зимовий король (Zimní král), Orfeus (Opø̧eŭ)(Slyvynskyj 2018: 5), z níž níže citujeme část: 
„Насправді ияя історія

має передісторію, івона-

про малого, який боявся води.

Aле ймов з усіма на берег і видряпувався

на довгий камінь,

i коли хлопиі стрибали у море, він залишався

стояти там, худий і розгублений,

і дивився, як віддаляються

голови у віялах бризок,

сподіваючись лище на одне -

що жодна з них не озирнеться.

А далі рушав до ближніх

будинків, стинаючи від безсиля

голови чортополохів, інакший, ніж усі тут -

подібний на мідну струну, випадково вплетенув вошик."
„Tento př́běh vlastně

má předpřiběh, a ten je

o chlapci, který se bál vody.

Ale šel se všemi na břeh a vyškrábal se

na dlouhý kámen,

a když kluci skákali do moře, on zůstal

stát tam, hubený a zmatený,

a dival se, jak se vzdalují

hlavy ve vějiríich cákanců,

a doufal jen $v$ jediné -

že se žádná z nich neohlédne.

A pak se vydal k blízkým

domům a u toho stínal v bezmocnosti

hlavy bodláki̊,

jiný, než všichni tady -

podobný měděné struně, náhodou

vpletené do košíku.

Orfeus obsahuje vlastně vše, co charakterizuje nejnovější a nejvyspělejší tvorbu Slyvynského: tíhnutí k narativnosti, blízkost k podobenství, minimum metafor, empatický př́stup k lyrickému hrdinovi a postavám.

Zmíněná báseň navíc otevírá jedno důležité téma: odlišnost, cizost, jinakost. V různých podobách je leitmotivem celé sbírky Zimní král a vlastně celé autorovy tvorby. Díky tomu, že se objeví hned v prvním textu, výrazným zpơsobem směřuje čtenářské očekávání. Slyvynského lyrické hrdiny nejčastěji nacházíme na okraji společnosti, kde se ocitli z různých důvodů - někteří z nich jsou dobrovolní samotáři, někteří od lidí utíkají, jiné od sebe lidé sami vyhánějí. Všichni tak sdílí tutéž zkušenost osamění či nepochopení a s tím spojených traumat.

Slyvynskyj v textech opatrně prozkoumává okamžiky, které vedly k formování osobnosti právě tímto směrem. Speciální pozornost věnuje křehkému dětskému věku, nebot právě tehdy se podle něj do vědomí zapisují prožitky nejsilněji. Ilustruje to např́klad trojdílná báseň Icmopii (Př́běhy), resp. její druhá část, z níž pochází následující úryvek (Slyvynskyj 2018: 7-8). Lyrický mluvčí vzpomíná (respektive se přiznává), jak se podílel na ponížení kamaráda. Při nevinné dětské hře s kamarády vyráběl z cihly nadrobené do vody „kávu“ pro ptáky. Následovalo však pochopitelné rozčarování: ptáci sice poletovali okolo, ale nenapil se žádný z nich. 
„Ми розуміли, що з кавою щось не так.

Угорі хтось плеснув у долоні, з гілки

зірвались чужі птахи.

Треба було куштувати, але

бракувало відважних.

I тоді ми згадали про найменшого з нас,

Вадика чи Віталіка,

від якого у пам'яті замість імені-

лише мовчазність і криво підрізана гривка.

Він не пручався, майже. Після

перших розлитих крапель пив

дрібними ковтками буру мутну

рідину. Нарешті нам стало лячно,

ми побігли за ріг і лише визирали. Він

міг утікати чи принаймні відкласти

заболочену банку, але пив і пив.

I, тільки випивщи майже все, почав плакати.“
„Chápali jsme, že s kávou není něco v pořádku.

Nahoře někdo tlesknul, $z$ větve

odletěli cizí ptáci.

Museli jsme to ochutnat, ale

chyběli odvážní.

A tehdy jsme si vzpomněli na nejmenšího z nás, Vadyka nebo Vitalika, pro něhož v paměti místo jména zbyla jenom mlčenlivost a křivě zastřižená ofina.

Nevzpiral se, skoro. Po

prvních rozlitých kapkách pil

drobnými doušky hnědou kalnou

tekutinu. Nakonec jsme se začali bát, utekli jsme za roh a jen jsme vykukovali.

Mohl utéct nebo alespoň odložit

zablácenou sklenici, ale on pil a pil.

A teprve když vypil skoro vše, rozplakal se."

Lyrický mluvčí, který vypráví celý příběh, v sobě musel nalézt odvahu vzpomínat na dávné události, vyslovit je nahlas a přiznat (nebo si vlastně teprve v úplnosti uvědomit) své pochybení - je to tedy svým zpo̊sobem terapie. Také je třeba zdůraznit i (Vadykův nebo Vitalikův) pocit strachu z nepřijetí - ten je motivem, který u Ostapa Slyvynského rozhodně není ojedinělý.

Titulní postava sbírky Zimní král je osobou, která se ocitla na okraji společnosti. Zatímco většina lidí tohoto starce (či snad místního blázna) obchází obloukem nebo o něm ani neví, jsou to děti, kdo v něm spatřuje výjimečnou osobu a váží si ho. Jejich světy se totiž nesou na společném principu př́močarosti a neznalosti přetvářky. Sám Slyvynskyj o dalším aspektu postavy zimního krále říká:

„Hrdina je pro tuto knížku velmi symbolický. Spojuje v sobě dětství a stáří. Od dětství ke stáří vede mnohem kratší most, než se nám zdá. Je pro mě velice důležitý dialog člověka, který prožil životní cyklus a nashromáždil tolik životních zkušeností, že je lze předat jen jednoduchými slovy, jaká jsou srozumitelná dětem.“(Slyvynskyj 2019)

Pro děti je každé setkání s králem neobyčejně důležitou událostí, částečně tyto cesty k němu a debaty s ním vnímají jako své poslání, jako svưj rytířský úkol, což můžeme chápat také jako způsob iniciace. Bezstarostná dětská zábava je však v závěru básně doplněna o znepokojivé otázky, které si lyrický subjekt nyní v dospělosti klade (Slyvynskyj 2018: 28-29). 
„Він радо грав з нами в ию гру, аждоки не втомлювався і не

засинав на скрипучому троні, випускаючи з рук скіпетр з індичого пір'я. Наш квітневий король, і король серпневий, і осінній король, і ніколи - король зимовий, бо зимою-сніги й ранні тіні, і замітало схил, яким вела єдина дорога до нього.

(...)

Ми обережно виходили з дому задньою хвірткою,

ідучи, готували для нього добірку новин: хлопиі з Лугів програли, иукор кипіть на гарячому камені, один утопився, заснувши в човні. Бувало, він чемно вдягав корону, шойно ми заходили в сад, а часом вередував, $і$ тодi нам треба було розгадувати його загадки, загадки, на які він і сам не знав відповіді,

\section{й лище}

махав рукою, сміючись із нашого заповзяття. Після трапези й чаркування компотом був час аудієниій,

і ми ставали по обидва боки трону зі смерековими списами, суворі і насторожені, бо казна-хто міг прийти до нашого короля.

I хтось приходив щоразу, а хто?

Чи приходили ті, кому такожв в'язали рукави за спиною? Чи приходили ті, хтов в'язав, щоб попросити у нього невчасне пробачення? Чи приходили mi, хто забув його за роки хвороби іусамітнення, щ,об навести лад у власних нотатках? Чи приходила жінка, щзоб довго-довго дивитись, а потім повернутися до чоловіка в машині, відкупившись Божим заступництвом? (...) “
„Rád s námi hrál tu hru, až dokud se neunavil a neusnul na rozvrzaném trůnu a pustil z rukou žezlo z krocaního peř́. Náš dubnový král a král srpnový, a podzimní král a nikdy král zimní, protože v ziměje sníh a časné stiny, a zaválo to svah, kterým vedla jediná cesta kněmu.

(...)

Opatrně jsme vycházeli z domu zadní brankou, po cestě jsme pro něj chystali výběr novinek: kluci z Luhủ prohráli, cukr kypí na horkém kameni, kdosi se utopil, když usnul v lod'ce. Stávalo se, že si zdvořile nasazoval korunu, jen co jsme vešli do sadu, a občas ho prepadly rozmary,

$$
\text { a to }
$$

jsme pak museli hádat jeho hádanky, hádanky, na které ani on sám neznal odpověd', ajenom mával rukou a smál se našemu zápalu. Po hostině a prípitku št'́vou byl čas audiencí a my jsme stáli po obou stranách trůnu se smrkovými kopími, prísní a ve střehu, protože kdovíkdo mohl k našemu králi prijít. A někdo pricházel pokaždé, ale kdo? Přicházeli ti, kterým taky vázali rukávy za záda? Nebo přicházeli ti, kdo vázali, aby u něj požádali o opožděné odpuštění? Nebo pricházeli

ti, kdo na něj zapomněli za roky nemoci a osamění, aby si udělali pořádek ve vlastních poznámkách? Nebo přicházela žena, aby se velmi dlouho dívala a potom se vrátila za mužem do auta, vykoupena Božím zastoupením?

(...) “ 
Celá sbírka Zimní král také často otevírá téma vztahu syna k otci, které se zde objevuje v různých podobách. Zvlášt citlivá je báseň Менший (Slyvynskyj 2018: 21), v níž syn k otci promlouvá. Činí to důvěrně a starostlivě, je možné pozorovat pomalu přicházející křehký obrat - moment, kdy synové přebírají od svých otců rodičovskou úlohu a sami se stávají těmi, kdo začínají pečovat, dělat si starosti. Text se navíc dotýká znepokojujícího tématu pronásledování a perzekucí.

„Тут хтось приходив до тебе, mamy.

Сказав, що наступного разу прийде не сам.

(...)

Я його не боюся й не хочу, шюб ти боявся.

У мене ємеч.

Я знаю такі слова, які його відженуть, are 3 apas

не моху їх повторити, бо вони не розбирають, де чужі, де свої.

Я знаю багато тварин, які нас захистять. Уві сні до мене приходив великий японеиь i навчив мене битися. А щзе під пахвою умене виросла спеціальна кнопка, але ти не кажи нікому. Вона трохи болить.

Якщь переслідіють, досить ї̈ натиснути i mезаєm

раз і назавжди. Пообіияяй,

ш,о не будеш з ним домовлятися, шоо не підеш на ніяке призначене місие, не будеш приймати від нього дарунків. Що навіть собаку його

не погладищ.

Вусьому решта мудріший-ти.

(...) “
„Někdo tu za tebou byl, tati.

Řekl, že př́šš̌ neprìjde sám.

(...)

Já se ho nebojím a nechci, aby ses ho bál ty.

Mám meč.

Znám taková slova, která ho odeženou, ale ted' je nemůžu zopakovat, protože ony nerozumí, kde jsou cizí, kde my.

Znám mnoho zvírat, která nás ochrání.

Ve snech mě navštěvoval velký Japonec

a naučil mě bojovat. A ještě mi v podpaží

vyrostlo speciální tlačitko, ale

nikomu to neříkej. Trochu mě bolí.

Když tě pronásledují, stači ho stisknout - a zmizišs

jednou a napořád. Slib,

že se s ním nebudeš domlouvat, že

nepůjdeš na žádné určené místo, nebudeš

od něj prijímat dárky. Že ani jeho psa

nepohladís.

Ve všem ostatním jsi moudřejši ty.

(...) “

\section{2 / PUTOVÁNí MEZI TEXTY}

V ukrajinské nakladatelské praxi je poměrně častým zvykem, že vydává-li básník sbírku, do nové knihy zároveň zařazuje i vybrané básně z předešlé tvorby. V některých př́padech potom bibliografie autora vyvolává dojem, že jde o velmi plodného spisovatele, avšak při pečlivějším prolistování knih zjištujeme, že jde doslova o recyklaci. Zdaleka ne vždy má takové rozhodnutí za sebou nějaký hlubší umělecký smysl. To ale neplatí pro zmiňovanou sbírku Zimní král.

Ta obsahuje takřka polovinu již dříve publikovaných básní. V autorově tvorbě však můžeme vysledovat nejen linii témat, ale i postav, které putují z jedné sbírky do druhé a postupně se vyvíjejí. Zařazení textů do jedné knihy tak umožňuje celý tento proces hlouběji sledovat.

Jednou z takto putujících postav je Adam, který vystupuje nejen v jednotlivých básních (objevuje se už v debutu), ale taky mu bylo přiděleno čestné místo př́imo v titulu sbírky - Adam 
(2012). Adam je klíčová biblická postava a také Slyvynského osobní literární hrdina, čímž dochází k prolnutí sakrálního a profánního aspektu.

Postava starozákonního Adama je obecně v literatuře značně rozšířená, různí autoři v jeho př́běhu a charakteru zdůrazňují různé rysy. $V$ české literatuře bychom dokonce nalezli takového Adama, který se velice podobá Adamovi Slyvynského. Tento Adam obývá básnický fikční svět Petra Hrušky. A stejně jako Slyvynskyj, i Hruška má Adama jako postavu procházející celou jeho tvorbou. Zatím poslední Hruškova sbírka Nikde není řečeno (2018) obsahuje dokonce celý oddíl, v němž jsou shromážděny všechny jeho dosavadní „adamovské“ básně.

Adam Ostapa Slyvynského a Adam Petra Hrušky by si mohli navzájem nepozorovaně vyměnit místa. Oba jsou ve své naivitě a nezkaženosti nepochopeni, polapeni světem. Hruškův Adam je nejprve dítětem, potom roste a setkáváme se s ním i v jeho dospělosti - v každém věku je však jaksi výlučný, jako by úplně nepatřil do tohoto světa, křehký a v lecčems nechápavý. Adam Ostapa Slyvynského se nejčastěji objevuje v podobě dospělého muže, který je také čímsi neustále dětinský, směšný, k politování. Takto je třeba zobrazen v jedné z básní (Slyvynskyj 2012: 38):

„Старий, а впійманий удитячий сак!

На п'ятій тисячі років прокинутися

з розмальованою вві сні

Лисиною!

Хто я? Розгублений дідуган у костюмі фбавна.

I dimu

хапають мене за руки, щоб провести крізь

діру в огорохі

do cady,

де сторожем - мій бородатий приятель

юності.
„Starý, a chycený do dětské sítě!

Po pěti tisících let se probudits

ve spánku pomalovanou

Pleší!

Kdo jsem? Zmatený dědek v kostýmu fauna. A děti chytají mě za ruce, aby mě provedly dírou v ohradě do sadu, kde je hlídačem můj vousatý přitel mládí.

(...).“

\section{3 / INTIMITA JAKO NEJVYŠŠÍ CÍL}

Celou tvorbou Ostapa Slyvynského se prolíná téma intimity. Básník ji vnímá jako základní předpoklad dobře fungujících mezilidských vztahů. Intimita má mnoho podob - od ryze fyzické, tj. schopnosti být vedle sebe, až k duševní, která se projevuje důvěrou, sdílením myšlenek, vzájemnou empatií nebo i jen chvilkou mlčení. Takové okamžiky mezilidské blízkosti zobrazené v básních mají nezřídka charakter takřka až posvátného okamžiku.

Lyrický subjekt přímo touží po blízkosti a kontaktu, po možnosti sdílet s někým svou zkušenost - a je si vědom toho, že ne vždy je to jednoduché. V doslovu ke sbírce M'яu y nimbmi (Míč ve tmě) si Serhij Žadan všímá, že v knize až neobvykle často dochází k tematizaci všemožných komunikačních kanálů (telefon, rádio, pošta, hlas atd.).

Texty jsou také plné množství filozofujících otázek. Obvykle se stírá hranice mezi tím, zda jsou součástí vnitřních úvah lyrického mluvčího, nebo se jimi lyrický mluvčí obrací na 
společníka. Některé z nich sice lze vnímat jako řečnické, nicméně většina v sobě nese touhu po zodpovězení nebo alespoň společném hlubokém zamyšlení.

Snaha porozumět jeden druhému, uvědomění si důležitosti dobrých vzájemných vztahů a hlavně nezbytnosti na nich pracovat, to jsou klíčová témata Slyvynského básní. Slyvynskyj si dává záležet na klidném, přemýšlivém, rozvážném tónu. Svým naladěním vlastně mají blízko až k určité formě poselství.

\section{4 / VÁLEČNÉ STOPY}

Autor v největší části svých textů reflektuje vnitřní pohnutky a osobní př́běhy, avšak události na Majdanu a válka na východě země ho přiměly vykročit za tyto hranice a do jeho básní se přece jen promítly. Zůstává ale věrný svému způsobu psaní - nejvíce ho opět zajímají všeobecné pocity spjaté s válkou, nebezpečím a nejistotou. Válka (ne nutně válka současná, ale spíš obecný obraz války) je tedy prostředek k tomu, aby mohl odkrýt další vrstvy lidské psychiky. V jedné z básní se dostává do popředí př́klad, jak lidé zachraňují svou mysl před hrůzami tím, že si je nepřipouštějí nebo př́mo vytěsňují, a místo toho se soustředí na banality. Citujeme úryvek (Slyvynskyj 2018: 53):

\section{„Старий}

так $і$ не зрозумів, що пережив.

(...)

Шкодував двох ковдр, які забрала війна.

Годував курей, кривди пробачав.

Повалений кулаком на землю, збирав монети, що висипались

3 кишені.“
„Stařik

ani nepochopil, co prožil.

(...)

Litoval dvou peřin, které vzala válka.

Krmil slepice, odpouštěl křivdy.

Povalený pěstí na zem,

sbiral mince, které se vysypaly

z kapsy."

V básni Лrmiøa (Latifa) (Slyvynskyj 2018:34) se objevuje odvěký motiv vyhnání z domova a emigrace. Pozoruhodná je podvědomá snaha rodiče přemoci svou nenávist vưči tomu, kdo situaci způsobil, a s klidem, zjednodušeně a dokonce s půvabnou fantazií vysvětlit dítěti, co se děje.

\section{„(...)}

А я якось каху, мовляв, дім наш забрали на небо. Не знаю, шо тоді на мене найшло. Каху: він був такий добрий до нас, Aліме, щзо не міг більще стояти на зелмі, як усі інші доми. (...) “
„(...)

A já najednou ř́kám něco jako, že náš dưm vzali do nebe. Nevím, co mě to tehdy popadlo. Říkám: byl na nás tak moc hodný, Alime, že už nemohl stát na zemi, jako všechny ostatní domy.

(...)

V souvislosti s válečnou tematikou se v nejnovější sbírce objevuje také několik haiku, pro básníka do té doby netypický formát. $V$ jednom z rozhovorů autor vysvětluje, kde mají svůj původ: „Dřiv jsem o takovém žánru nikdy neuvažoval, protože se mi vždycky chtělo psát dlouhé a výpravné 
texty. Na Majdanu jsem začal psát haiku, protože na nic víc nebyl čas. Jiný důvod spočívá v tom, že bylo velice těžké reflektovat věci, které se odehrávaly. V tomto žánru je lehké zachytit věci bez reflexe. Je to jenom náčrt, který nás k něčemu podněcuje." (Slyvynskyj 2019). To dokazuje např. ukázka z „majdanského“ cyklu Хаŭкy революцїі (Haiku revoluce) (Slyvynskyj 2018: 23):

„Дим у рукавах.

Ніби йдеш з иими людьми

лісистим хребтом.“
„Kouřv rukávech.

Jako bys šel s těmi lidmi

zalesněným hřebenem."

\section{5 / NENÁPADNÝ TRIUMF}

Ačkoli jsme v úvodu nastínili, že básnickou tvorbu Ostapa Slyvynského lze zařadit ke spirituální poezii, ukazuje se, že tato kategorie nakonec říká o jeho poetice jen velmi málo a velmi zkresleně. $\mathrm{V}$ jeho poezii nejde o hledání cesty $\mathrm{k}$ Bohu, o ujasňování si svého vztahu $\mathrm{k}$ víře, vlastně ani ne o nějaké ryze etické otázky. Křestanství je pro Slyvynského mnohem spíše jen širokým kulturním kontextem, ve kterém se nacházíme a ke kterému se nějak vztahujeme. Z Bible ho nezajímá to, co nás přesahuje, ale naopak to, co je veskrze lidské, a to včetně všeho našeho váhání, chybování, scházení ze správné cesty a jejího opětovného nalézání.

Úskalím takto laděné poezie bývá pro mnohé autory sklon $\mathrm{k}$ nadbytečné sentimentalitě či patetickým vyjádřením. O to více se s tím setkáváme na poli ukrajinské poezie, pro kterou je tato rovina tradičně v jisté míře přirozená a zakořeněná, takže je náročné se od ní odpoutat. Právě proto je Ostap Slyvynskyj se svými texty neobyčejným autorem. A především Zimní král, zatím jeho poslední a zřejmě i nejsilnější sbírka, ukázala, že pokud se sentimentalita a patos nahradí otevřeností, empatií a prostotou výrazu, vzniknou nepřehlédnutelné texty s naléhavým sdělením.

Př́spěvek vznikl za podpory MŠMT, grant IGA_FF_2019_012 - Text a intertextualita ve slovanských literaturách a kultuře III.

\section{A SILENT CELEBRATION OF DISSIMILARITY. EMPATHETIC POETRY OF OSTAP SLYVYNSKY}

SUMMARY This paper deals with poetry of contemporary Ukrainian poet Ostap Slyvynsky who is considered to be one of the most important authors in Ukraine nowadays. His texts are close to spiritual poetry, however, they are not about finding a way to God, not about realizing a view on religion nor about ethical questions. For Slyvynsky, Christianity is a rather wide cultural context in which we exist and to which we somehow relate to. For him, the Bible is a source of stories about human hesitation, making mistakes, losing the right way and finding it again. In his five poetry collections published so far he often looks for paralels in our ordinary life and biblical or mythological stories. He stresses the role of childhood experiences in forming one's identity. He concentrates on fragile 
interpersonal relationships, the importance of a dialog and listening. His (anti-) heroes have to cope with dissimilarity and rejection and that is also very significant. In Slyvynsky's poetry, sentimentality and pathos are replaced by sincerity and empathy - that is why his texts are so noticeable and offers a serious message.

\section{LITERATURA}

I Сливинський О., 2019, «Зимовий король»- ие сільський божкевільний, https://starylev.com. ua/news/zymovyy-korol-ce-silskyy-bozhevilnyy-ostap-slyvynskyy. [cit.: 26. 9. 2019]

I Сливинський, О., 2018, Зимовий король, Львів.

I Сливинський, О., 2012, Адам, Чернівці.

I Сливинський, О., 2008, М'яч у пітьмі, Київ.

I Сливинський, О., 2004, Полуднева лінія, Хмельницький - Київ.

I Сливинський, О., 1998, Жертвоприношення великої риби, Львів. 